\title{
ON THE MODE OF ACTION OF CRYOMYCIN
}

\author{
Noboru Yoshida, Hideyukr Hanochi, Yukio Hachiya, \\ Yoshimi Tani and Korchi Ogata
}

Department of Agricultural Chemistry, Kyoto University, Sakyo-ku, Kyoto, Japan

(Received for publication October 19, 1972)

\begin{abstract}
The mode of action of cryomycin upon Staphylococcus aureus IFO 3061 and Bacillus subtilis IFO 3037 has been investigated. Cryomycin inhibited the syntheses of protein, RNA and DNA to almost the same degree. It caused a rapid increase of endogenous and exogenous respiration in the test organisms at minimum growth inhibitory concentrations. It was concluded that the primary effect of cryomycin was on the coupling of oxidative phosphorylation followed by secondary effects such as membrane damage, and protein and nucleic acid syntheses. Cryomycin also caused the leakage of $\mathrm{A}_{260 \mathrm{~m} \mu}$ absorbing materials from most of the Bacillus species.
\end{abstract}

Cryomycin is a new peptide antibiotic isolated in our laboratory. It is produced only at low temperatures by Streptomyces griseus subsp. psychrophilus AKU 2881. Its production, isolation and properties were described in preceding papers., ${ }^{1,2}$ Cryomycin strongly inhibits the growth of Gram-positive bacteria, and less effectively the growth of Gram-negative bacteria, yeasts and fungi.

Since cryomycin is a unique substance isolated from a psychrophilic Streptomyces, its mode of action has been studied using sensitive microorganisms. In this paper, we wish to report that the primary effect of cryomycin is on respiration.

\section{Materials and Methods}

1. Strains: Bacillus subtilis IFO 3037 and Staphylococcus aureus IFO 3061 were used.

2. Culture medium: The following nutrient medium was used for the growth of test organisms. Thirty $g$ Nissan Dry Bouillon (Nissui Seiyaku Co., Ltd.) was dissolved in $1,000 \mathrm{ml}$ of tap water. The composition of the medium was peptone $1.5 \%$, meat extract $0.5 \%, \mathrm{NaCl} 0.5 \%$ and $\mathrm{K}_{2} \mathrm{HPO}_{4} 0.5 \%, \mathrm{pH} 7.0$ before sterilization.

3. Growth of bacteria: The turbidity at $610 \mathrm{~m} \mu$ was measured. The number of viable cells was determined by plating.

4. Leakage of cellular constituents: Growing cells were suspended in a fresh medium at appropriate dilutions and shaken in the presence or absence of the antibiotic at $30^{\circ} \mathrm{C}$. At various time intervals, aliquots were withdrawn, cells were removed by centrifugation $(3,000 \times \mathrm{g}$ for $10 \mathrm{minutes})$, and the presence of $260 \mathrm{~m} \mu$ absorbing material in the medium was determined.

5. Protein, DNA and RNA syntheses: Cells were grown overnight at $30^{\circ} \mathrm{C}$, washed, resuspended with 20 -fold dilution in a fresh medium and shaken. After a two-hour incubation, the drug was added to the medium. At appropriate time intervals, aliquots were withdrawn and the contents of RNA, DNA and protein were measured after ScHMDTThannhauser-Schneider fractionations ${ }^{3 \sim 5)}$ by the absorbancies, at $260 \mathrm{~m} \mu$ and $280 \mathrm{~m} \mu$ for nucleic acids and protein, respectively.

6. Endogenous and exogenous respiration: Cells were grown overnight at $30^{\circ} \mathrm{C}$, 
washed with saline, suspended in $\mathrm{M} / 15$ phosphate buffer, $\mathrm{pH} 7.0$, and shaken for a few hours to reduce autorespiration; the cells were washed again and resuspended in the same buffer. A conventional WARBURg technique was used. A cell suspension $(0.5 \mathrm{ml})$ of ca. $2 \mathrm{mg} / \mathrm{ml}$ dry weight was placed in the side arm. The main compartment contained $0.2 \mathrm{ml}$ of $2.7 \mathrm{mg} / \mathrm{ml}$ glucose for exogenous respiration or buffer for endogenous respiration, $0.5 \mathrm{ml}$ of the antibiotic, and $1.1 \mathrm{ml}$ of the buffer. In the center well, $0.2 \mathrm{ml}$ of $20 \%$ potassium hydroxide was placed with a tip of filter paper. Gas phase was air. Incubation was carried out at $37^{\circ} \mathrm{C}$, and the oxygen uptake was measured periodically.

7. Preparation of rat liver mitochondria: Rat liver mitochondria were prepared by the method of SchNeIDER ${ }^{6)}$. Rat liver was gently homogenized in a solution of $0.25 \mathrm{M}$ sucrose, $10 \mathrm{~mm}$ potassium chloride, $0.2 \mathrm{mM}$ EDTA, $5 \mathrm{~mm}$ magnesium chloride, $20 \mathrm{~mm}$ tris (hydroxymethyl) aminomethane hydrochloride buffer, pH 7.2, and centrifuged at $700 \times \mathrm{g}$; the supernatant was centrifuged at $7,000 \times g$ and the pellet was collected as the mitochondrial fraction. The oxidase activity was measured with an oxygen-meter ${ }^{7}$ in a mixture of $2.75 \mathrm{ml}$ of $0.25 \mathrm{M}$ sucrose, $10 \mathrm{~mm}$ potassium chloride, $10 \mathrm{~mm}$ tris (hydroxymethyl) aminomethane hydrochloride buffer, $\mathrm{pH} 7.2,5 \mathrm{mM}$ potassium phosphate buffer, $\mathrm{pH} 7.2,5 \mathrm{mM}$ magnesium chloride, $0.2 \mathrm{mM}$ EDTA, $0.1 \mathrm{ml}$ of mitochondrial suspension ( $c a .5 \mathrm{mg}$ protein), $0.05 \mathrm{ml}$ of substrate (final $10 \mathrm{mM}$ ) $0.05 \mathrm{ml}$ of ADP solution (final $0.6 \mathrm{~mm}$ ), and $0.05 \mathrm{ml}$ of inhibitor in a total of $3.0 \mathrm{ml}$ at $25^{\circ} \mathrm{C}$. The ATPase activity was measured as inorganic phosphorus released in the reaction medium containing $10 \mathrm{mM}$ tris (hydroxymethyl) aminomethane hydrochloride buffer, $\mathrm{pH} 7.2,75 \mathrm{~mm}$ sucrose, $75 \mathrm{~mm}$ potassium chloride, $0.01 \mathrm{ml}$ of water or cryomycin solution, and $0.05 \mathrm{ml}$ of mitochondrial suspension ( $c a .3 \mathrm{mg}$ protein) in a total of $1 \mathrm{ml}$. The reaction was started by the addition of $5 \mu$ moles of ATP. Incubation was carried out for 10 minutes at $30^{\circ} \mathrm{C}$. Inorganic phosphorus was measured by the method of TAKAHASHr. ${ }^{81}$

8. Autolysis of Bacillus species: $0.5 \mathrm{ml}$ of an overnight culture of each strain was added to $4.1 \mathrm{ml}$ of fresh broth medium and incubated at $28^{\circ} \mathrm{C}$. At the appropriate time of the exponential growth phase of the organism, $0.4 \mathrm{ml}$ of cryomycin solution at a final concentration of 5 or $20 \mathrm{mcg} / \mathrm{ml}$ was added to the medium, and the incubation was continued. The turbidity was periodically measured at $610 \mathrm{~m} \mu$.

9. Autolysis of Bacillus subtilis: Preparation of autolytic enzymes: Two-day cultured broth filtrates of $B$. subtilis IFO 3037 were used as the source of the exocellular enzymes. A sonicate of the cells was used as the source of the endocellular enzymes. Growing cells of $B$. subtilis were suspended in $\mathrm{M} / 15$ potassium phosphate buffer, $\mathrm{pH} 7.0$, containing $0.7 \mathrm{M}$ sucrose; $0.5 \mathrm{ml}$ of each autolytic enzyme solution or buffer as a control, and $0.5 \mathrm{ml}$ of cryomycin solution at a final concentration of 0,5 or $20 \mathrm{mcg} / \mathrm{ml}$ were added to $4 \mathrm{ml}$ of the cell suspension. Incubation was carried out at $37^{\circ} \mathrm{C}$. At appropriate time intervals, the turbidity at $610 \mathrm{~m} \mu$ was measured.

\section{Results}

\section{Effect on Growth}

Figs. 1 and 2 show that the growth of Staphylococcus aureus and Bacillus subtilis is inhibited by cryomycin. The minimum growth inhibitory concentrations against $S$. aureus and $B$. subtilis were 20 and $5 \mathrm{mcg} / \mathrm{ml}$, respectively. Concentrations greater than $5 \mathrm{mcg} / \mathrm{ml}$ of cryomycin caused a rapid decrease of cell turbidity of $B$. subtilis.

Fig. 1. Effect of cryomycin on the growth of Staphylococcus aureus IFO 3061.
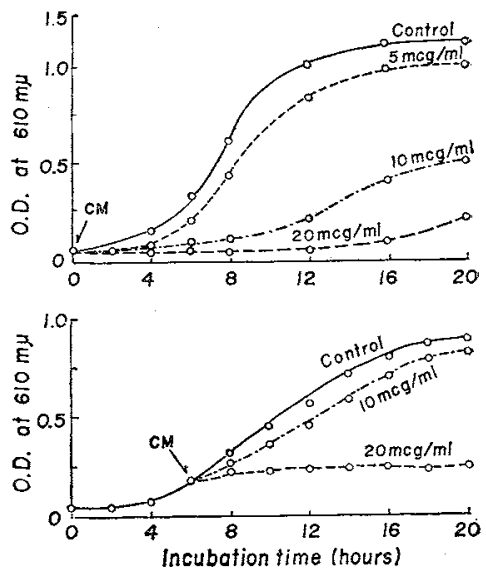
Fig. 2. Effect of cryomycin on the growth of Bacillus subtilis IFO 3037.
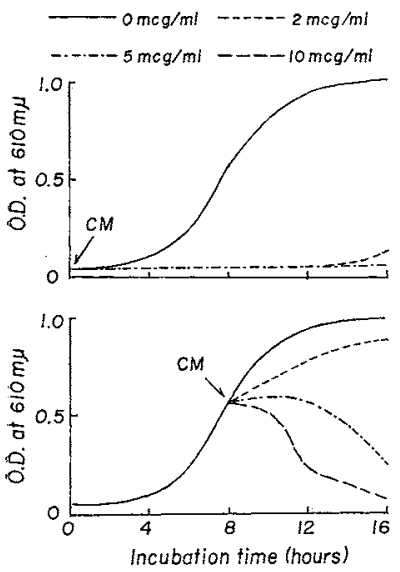

As shown in Table 1 , cryomycin showed a bactericidal action rather than a bacteriostatic one against the test organisms.
Table 1. Effect of cryomycin on cell growth and viability

\begin{tabular}{c|c|c|c}
\hline $\begin{array}{c}\text { Cryomycin } \\
(\mathrm{mcg} / \mathrm{m} 1)\end{array}$ & $\begin{array}{c}\text { Length of } \\
\text { incubation } \\
\text { (hrs.) }\end{array}$ & \multicolumn{2}{|c}{ Viable cells (per ml) } \\
\hline 0 & 0 & $4.8 \times 10^{8}$ & $1.1 \times 10^{8}$ \\
0 & 1 & $5.5 \times 10^{8}$ & $5.9 \times 10^{8}$ \\
0 & 3 & $1.1 \times 10^{9}$ & $1.3 \times 10^{9}$ \\
10 & 1 & $6.2 \times 10^{8}$ & $1.9 \times 10^{6}$ \\
10 & 3 & $5.0 \times 10^{8}$ & $4.8 \times 10^{7}$ \\
20 & 1 & $4.2 \times 10^{7}$ & $4.8 \times 10^{6}$ \\
20 & 3 & $3.7 \times 10^{7}$ & $9.6 \times 10^{5}$ \\
40 & 1 & $4.8 \times 10^{6}$ & $4.8 \times 10^{6}$ \\
40 & 3 & $1.6 \times 10^{5}$ & $8.0 \times 10^{5}$ \\
\hline
\end{tabular}

Fig. 3. Effect of cryomycin on nucleic acid and protein syntheses in Staphylococcus aureus IFO 3061.
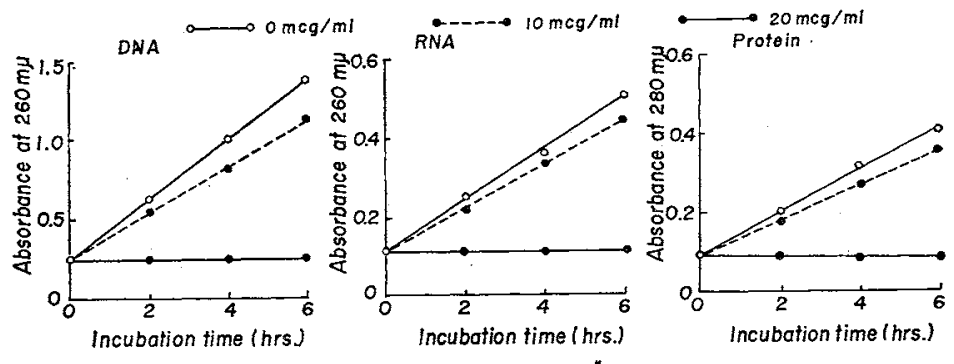

2. Effect on the Syntheses of Protein and Nucleic Acids

Cryomycin inhibits the syntheses of protein and nucleic acids to almost the same degree in S. aureus (Fig. 3). The same results were obtained in B. subtilis.

\section{Effect on Cell Membrane}

Fig. 4 shows that cryomycin causes the leakage of cellular constituents from B. subtilis. Only slight leakage was observed in S. aureus.

\section{Effect on Respiration}

Cryomycin at its minimum growth inhibitory concentration affects the respiration of the sensitive test organisms. Oxygen uptake in cultures of $S$. aureus was stimulated immediately after the addition of cryomycin (Fig. 5). The same results were obtained in $B$. subtilis.

Inhibition of respiration by cryomycin was investigated using rat liver mitochondria and the oxygen-meter method. As shown in Fig. 6,
Fig. 4. Effect of cryomycin on leakage of cellular constituents.

Reaction system : $267 \mu$ moles H.P. B. $C \mathrm{pH}$ 7.0), 2.8 mmoles sucrose, $4 \mathrm{mg}$ cells in $4 \mathrm{ml}$; $30^{\circ} \mathrm{C}$.
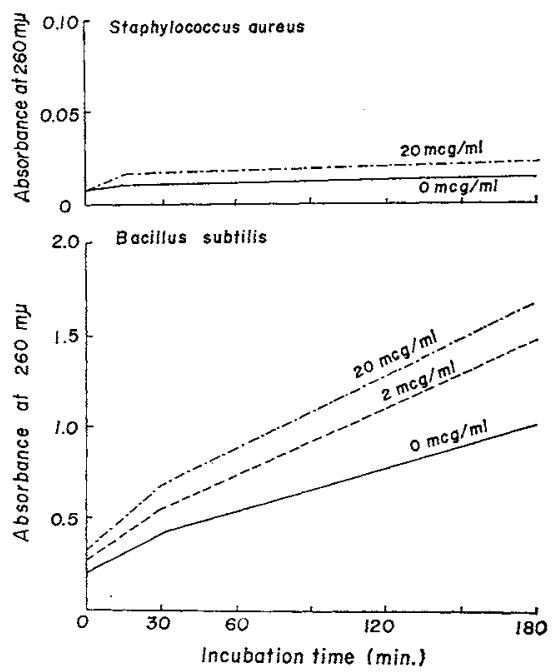
Fig. 5. Effect of cryomycin on respiration of $S$. aureus.

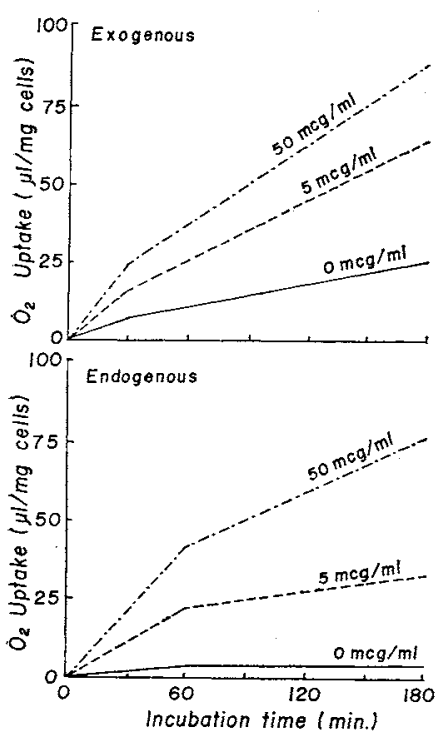

Table 2. Effect of cryomycin on ATPase

\begin{tabular}{c|c|c}
\hline $\begin{array}{c}\text { Cryomycin } \\
\text { (mcg/ml) }\end{array}$ & $\begin{array}{c}\text { Inorganic P released } \\
(\mu m o l e s)\end{array}$ \\
\cline { 2 - 3 } & Control* & $+10^{-5} \mathrm{M} \mathrm{DNP}$ \\
\hline 0 & 0.11 & 2.56 \\
10 & 0.18 & 2.88 \\
\hline
\end{tabular}

* The reaction systems are described in the text.

cryomycin stimulated respiration from 'step 3' to 'step 4' similarly to 2,4-dinitrophenol, a typical uncoupler of oxidative phosphorylation. Cryomycin did not activate ATPase (Table 2).

5. Effect on Autolysis of

\section{Bacillus Species}

High concentrations of cryomycin were found to induce autolysis of most of the microorganisms belonging to the genus
Fig. 6. Effect of cryomycin on the oxygen consumption of rat liver mitochondria.
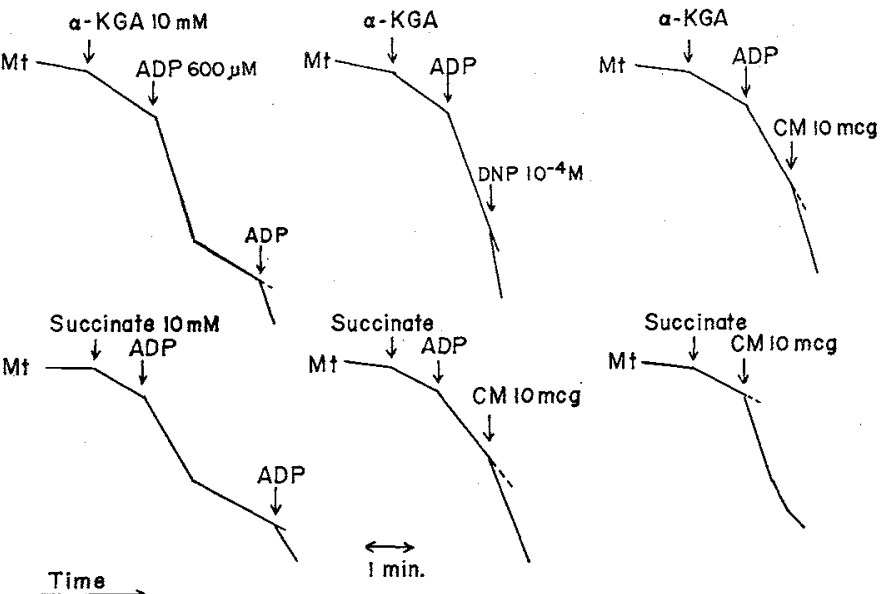

Time

Table 3. Effect of cryomycin on the autolysis of Bacillus spp.

\begin{tabular}{|c|c|c|}
\hline \multirow{2}{*}{ Microorganism } & \multicolumn{2}{|c|}{ Autolysis } \\
\hline & $5 \mathrm{mcg} / \mathrm{ml}$ & $20 \mathrm{mcg} / \mathrm{ml}$ \\
\hline B. aneurinolyticus AKU 0201 & \pm & ++ \\
\hline B. natto AKU 0205 & \pm & + \\
\hline B. pumilus IFO 3028 & \pm & + \\
\hline B. roseus IAM 1257 & \pm & ++ \\
\hline B. subtilis IFO 3007 & \pm & + \\
\hline B. subtilis IFO 3026 & - & ++ \\
\hline B. subtilis IFO 3037 & ++ & ++ \\
\hline B. subtilis IFO 3009 & \pm & $+t$ \\
\hline B. subtilis IFO 3022 & - & + \\
\hline B. subtilis IAM 1193 & \pm & ++ \\
\hline B. subtilis var. aterrimus IFO 3214 & - & ++ \\
\hline B. subtilis var, niger IFO 3108 & \pm & ++ \\
\hline B. sphaericus IFO 3525 & - & ++ \\
\hline B. brevis IFO 3331 & 一 & $+t$ \\
\hline B. subtilis $\mathrm{K}$ wild Ajinomoto & + & ++ \\
\hline B. licheniformis IAM 11054 & \pm & + \\
\hline B. subtilis Marburg W 23 AKU 0224 & - & - \\
\hline B. subtilis $\mathrm{K}$ AKU 0225 & \pm & ++ \\
\hline B. sphaericus IFO 3341 & + & ++ \\
\hline B. sphaericus IFO 3526 & - & + \\
\hline B. sphaericus IFO 3527 & \pm & + \\
\hline B. sphaericus IFO 3528 & 一 & ++ \\
\hline
\end{tabular}

$++:$ Rapid autolysis (within 1 hour after addition of $\mathrm{CM}$ )

+ : Delayed autolysis (within 2 or 3 hours)

\pm : No autolysis (growth markedly inhibited)

- : No autolysis (growth gradually continued)

When endocellular or exocellular autolytic enzymes were added to a cell suspension of $B$. subtilis, a rapid decrease of turbidity was observed with and without the addition of cryomycin. Without the addition of the enzyme solution, the decrease of turbidity caused by the inhibitor was delayed (Fig. 7). Upon a microscopic observation, most of the cells had burst; no spore formation was observed. 


\section{Discussion}

We suggest that the primary action of cryomycin is on respiration, especially on the coupling between oxidative phosphorylation and electron transport. This conclusion is supported by the fact that the inhibitor does not promote the ATPase activity of mitochondria at its respiration-stimulating concentration.

Gramicidin $^{9)}$ and valinomycin ${ }^{10)}$ are known to act as the uncouplers of oxidative phosphorylation, and their modes of action resemble those of cryomycin. The molecular weight of cryo-

Fig. 7. Effect of cryomycin on autolysis of Bacillus subtilis IFO 3037. A: Enzymes free B: Endocellular enzymes added. C : Exocellular enzymes added. Temperature : $37^{\circ} \mathrm{C}$

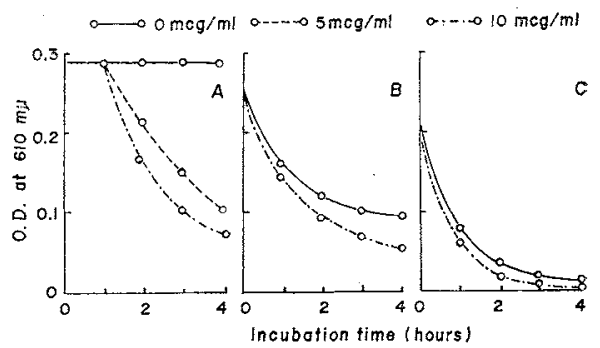
mycin is assumed to be ca. 4,000 (calculated as minimal molecular weight); the concentration causing the uncoupling is $10^{-6} \sim 10^{-5} \mathrm{M}$.

Since the respiration site of bacteria is believed to be located near the cell membrane, we would like to suggest that the abnormal respiration stimulated by cryomycin causes disruption of the cell barrier followed by lysis of the Bacillus species tested in these experiments.

Further studies on the mechanism of action of cryomycin on respiration and the correlation between the stimulated respiration and cell autolysis of $B$. subtilis will be presented in a subsequent publication.

\section{References}

1) OGata, K.; N. Yoshida, M. OHSUGi \& Y. Tanr : Studies on antibiotics produced by psychrophilic microorganisms. I. Production of antibiotics by a psychrophile, Streptomyces sp. No. 81 only at low temperature. Agr. Biol. Chem. 35:79 85, 1971

2) Yoshida, N.; Y. Tani \& K. Ogata: Cryomycin, a new peptide antibiotic produced only at low temperature. J. Antibiotics $25: 653 \sim 659,1972$

3) Schmidt, G. \& S. J. Thannhauser : A method for the determination of deoxyribonucleic acid, ribonucleic acid, and phosphoproteins in animal tissues. J. Biol. Chem. $161: 83 \sim 89,1945$

4) Schneider, W. C. : Phosphorus compounds in animal tissues. I. Extraction and estimation of deoxypentose nucleic acid and of pentose nucleic acid. J. Biol. Chem. $161: 293 \sim 303,1945$

5) Scrneider, W.C.: Phosphorus compounds in animal tissues. III. A comparison of methods for the estimation of nucleic acids. J. Biol. Chem. $164: 747 \sim 751,1946$.

6) Schneiner, W.C. : Intracellular distribution of enzymes. III. The oxidation of octanoic acid by rat liver fractions. J. Biol. Chem. $176: 259 \sim 266,1948$

7) Higashihara, B.: Techniques for the application of polarography to mitochondrial respiration. Biochim. Biophys. Acta $46: 134 \sim 142,1961$

8) TAKAhASHI, Y.: A method for the determination of true values of inorganic phosphate and creatine phosphate in animal tissues, and the action mechanisms of phosphoamidase and creatine phosphokinase in pig sperm. Biochemistry (Japan) $26: 690 \sim 698,1955$ (in Japanese)

9) Cross, R. J.; J. V. Taggart, G. A. Covo \& D. E. Green : Studies on the cyclophorase system. VI. The coupling of oxidation and phosphorylation. J. Biol. Chem. $177: 655 \sim 678,1949$

10) MoMurray, W.C. \& R. W. BeGG: Effect of valinomycin on oxidative phosphorylation. Arch, Biochem. Biophys. 84 : 546 548, 1959 